\title{
Analisis budaya dan iklim organisasi terhadap kinerja pegawai : studi kasus Politeknik Pertanian Negeri Pangkajene Kepulauan
}

\author{
Cultural analysis and organizational climate toward performance of employees: case study \\ Pangkep State Polytehnic of Agricultre
}

\author{
Wiwiek Hidayati $^{{ }^{*}}$ dan $_{\text {Arifah }}{ }^{1}$ \\ ${ }^{1} J u r u s a n$ Agribisnis, Politeknik Pertanian Negeri Pangkajene Kepulauan \\ ${ }^{*}$ Corresponding author: wiwiekhidayati78@gmail.com
}

Diterima tanggal 12 November 2019, Disetujui tanggal 07 Januari 2020

\begin{abstract}
Abstrak
Iklim organisasi menjadi unsur yang penting dalam institusi karena dapat memberikan nilai-nilai, sikap, serta meningkatkan kinerja pegawai dalam pencapaian institusi, karena nilai-nilai dari setiap individu yang berlainan harus diketahui oleh institusi agar dapat digunakan untuk menilai pegawai yang potensial dan menetapkan nilai-nilai segaris dengan nilai dominan institusi. Tujuan dari penelitian ini adalah mengetahui pengaruh budaya organisasi dan iklim organisasi terhadap kinerja pegawai pada Politeknik Pertanian Negeri Pangkajene Kepulauan (Politani Pangkep). Metode yang digunakan dalam penelitian ini adalah explanatory research dengan pendekatan kuantitatif.-Sampel dalam penelitian ini adalah pegawai Politani Pangkep sebanyak 100 responden. Metode analisis yang digunakan adalah regresi linier berganda. Berdasarkan hasil analisis deskriptif penelitian menunjukkan bahwa rata-rata skor distribusi jawaban responden untuk menilai variabel budaya organisasi $\left(X_{1}\right)$ skor sebesar 55,6, variabel iklim organisasi $\left(X_{2}\right)$ skor sebesar 55 , dan variabel kinerja pegawai $(\mathrm{Y})$ skor sebesar 56,4 . Hal ini membuktikan bahwa budaya organisasi, iklim organisasi dan kinerja yang dimiliki pegawai Politani Pangkep kuat. Secara parsial (uji t) pengujian variabel budaya organisasi terdapat pengaruh positif dan signifikan terhadap kinerja pegawai Politani Pangkep. Sementara itu, variabel iklim organisasi juga memiliki pengaruh positif dan signifikan terhadap kinerja pegawai. Secara simultan (uji f) hasil analisis regresi linier berganda diperoleh dari variabel bebas yaitu budaya oganisasi dan iklim organisasi yang memiliki pengaruh signifikan terhadap kinerja pegawai Politani Pangkep, bahwa kinerja pegawai dapat dipengaruhi secara signifikan oleh budaya organisasi dan iklim organisasi atau dengan meningkatkan budaya organisasi dan iklim organisasi maka kinerja pegawai akan mengalami peningkatan secara nyata.
\end{abstract}

Kata kunci: budaya, iklim, organisasi, kinerja, explanatory

\begin{abstract}
Organizational climate becomes an important element in the institution because it can provide values, attitudes, and improve employee performance in organizational achievement, because the values of each different individual must be known by the Institution so that it can be used to assess potential employees and determine values their value is in line with the dominant value of the institution. The purpose of this study was to determine the effect of organizational culture and organizational climate on the performance of employees in Pangkep State Polytehnic Of Agricultre (PSPA). The method used in this research is explanatory research with a quantitative approach. The sample in this study was 100 PSPA employees. The analytical method used is multiple linear regressions. Based on the results of descriptive analysis of the study showed that the average score distribution of respondents' answers to assess organizational culture variables $\left(X_{1}\right)$ score of 55.6, organizational climate variables $\left(X_{2}\right)$ score of 55 , and employee performance variables $(Y)$ score of 56.4. This proves that the organizational culture, organizational climate and performance of the employees of PSPA are strong. Partially (t-test) testing of organizational culture variables there is a positive and significant influence on the performance of PSPA. Meanwhile, organizational climate variables also have a positive and significant effect on employee performance. Simultaneously (f-test) the
\end{abstract}


results of multiple linear regression analysis were obtained from independent variables namely organizational culture and organizational climate which have a significant influence on employee performance in PSPA, that employee performance can be significantly influenced by organizational culture and organizational climate or by improving organizational culture and organizational climate, employee performance will increase significantly.

Keywords: culture, climate, organization, performance, explanatory

\section{PENDAHULUAN}

Organisasi merupakan kesatuan sosial yang dikoordinasikan secara sadar dengan sebuah batasan yang relatif dapat diidentifikasi yang dapat bekerja atas dasar relatif terus menerus untuk mencapai tujuan bersamadan sumber daya manusia sebagai faktor penggerak dalam kegiatan organisasi yang dituntut untuk dapat mengembangkan kreativitas, inovatif, dan memiliki dedikasi tinggi yang mampu memenuhi tantangan pekerjaan yang semakin penuh persaingan dan beragam (Robbins, 2008). Budaya organisasi merupakan sesuatu yang diterima oleh organisasi untuk dijadikan pedoman dalam memecahkan masalah, sehingga dapat membentuk pegawai yang mampu beradaptasi dengan lingkungan suatu organisasi. Budaya dan iklim organisasi dapat mempengaruhi kinerja pegawai dalam suatu institusi. Iklim organisasi menjadi unsur yang penting dalam organisasi karena dapat memberikan nilai-nilai, sikap, serta meningkatkan kinerja pegawai dalam pencapaian institusi, karena nilai-nilai dari setiap individu yang berlainan harus diketahui oleh institusi agar dapat digunakan untuk menilai pegawai yang potensial dan menetapkan nilai-nilai mereka segaris dengan nilai dominan institusi. Jumlah sumber daya manusia yang besar apabila digunakan secara efektif dan efisien dapat bermanfaat untuk mempengaruhi kinerja pegawai, karena iklim organisasi merupakan suatu metafora yang menggambarkan persepsi pegawai secara individual mengenai lingkungan organisasi mereka. Iklim organisasi akan mempengaruhi peraktik dan kebijakan sumberdaya manusia yang diterima oleh pegawai.

Setiap organisasi akan memiliki iklim organisasi yang berbeda. Keanekaragaman pekerjaan yang dirancang didalam organisasi, atau sifat individu yang ada akan menggambarkan perbedaaan tersebut. Menurut
Wirawan (2008), Iklim organisasi secara objektif eksis,terjadi disetiap organisasi, dan mempengaruhi prilaku anggota organisasi, tetapi hanya dapat diukur secara tidak langsung melalui persepsi anggota organisasi. Budaya organisasi dan iklim organisasi yang kondusif dapat membuat pegawai lebih termotivasi untuk meningkatkan kualitas kinerjanya. Kinerja pegawai merupakan hasil kinerja yang dapat dicapai oleh seseorang atau kelompok pegawai dalam suatu organisasi sesuai dengan wewenangan dan tanggung jawabnya. Kinerja Karyawan dalam kajian manajemen, pengertian kinerja (performance) didefinikan secara beragam oleh para ahli namun substansinya sama yaitu suatu output yang dihasilkan melalui prestasi kerja (Wibowo, 2014). Iklim organisasi menggambarkan lingkungan internal organisasi dan berakar pada budaya organisasi agar terbentuk good corporate governance sebagai prinsip dasar tata kelola institusi adalah sisi terluar dari keberhasilan transformasi tersebut. Dimana prinsip good corporate governance meliputi transparansi, yaitu keterbukaan dalam melaksanakan proses pengambilan keputusan dan keterbukaan dalam mengungkapkan informasi material dan relevan mengenai institusi atau lembaga; kemandirian, yaitu keadaan dimana institusi dikelola secara profesional, tanpa benturan kepentingan dan pengaruh/tekanan dari pihak manapun yang tidak sesuai (FCGI. 2001).Penetapan Politani Pangkep sebagai lokasi penelitian berdasarkan pertimbagan bahwa salah satu institusi pendidikan yang melakukan aktivitas pelayanan sebagai penyedia jasa.

Tujuan penelitian ini untuk mengetahui pengaruh budaya organisasi dan iklim organisasi terhadap kinerja pegawai pada Politeknik Pertanian Negeri Pangkajene Kepulauan (Politani Pangkep). 


\section{BAHAN DAN METODE}

\section{Waktu dan Tempat Penelitian}

Penelitian ini telah dilaksanakan pada Bulan Mei - Oktober 2019 bertempat di kampus Politani Pangkep, Kecamatan Mandalle, Kabupaten Pangkep.

\section{Jenis Data}

Data primer merupakan data yang diperoleh langsung dari objek penelitian yaitu dari hasil penyebaran kuesioner dan wawancara kepada pegawai di Politani Pangkep. Data sekunder dalam penelitian ini bersumber dari buku, web dan juga jurnal-jurnal yang terkait dengan budaya organisasi, iklim organisasi, dan kinerja karyawan, dan kondisi lingkungan sosial, organisasi Politani Pangkep.

\section{Metode Pengambilan Data}

Pengumpulan data dalam penelitian ini dilakukan dengan cara :

1. Kuisioner, digunakan untuk mengungkap persepsi pegawai terhadap atribut konflik dan motivasi kerja.

2. Studi Pustaka, mengumpulkan data-data sekunder yang berhubungan dengan obyek penelitian.

3. Observasi, melakukan pengamatan secara langsung terhadap obyek penelitian. Observasi ini dilakukan dalam rangka menghasilkan data kualitatif yang mendukung hasil analisis kuantitatif.

\section{Populasi dan Sampel}

Populasi dalam penelitian ini adalah pegawai Politani Pangkep dengan metode sampling. Cara penentuan sampel dengan menggunakan teknik purposive sampling. Sampel yang diambil dalam penelitian ini sebanyak 100 responden.

\section{Analisis Data}

Peneliti menggunakan explanatory research, karena penelitian ini mempunyai tujuan menguji hipotesis untuk mengetahui ada tidaknya hubungan antara variabel independen yaitu budaya organisasi dan iklim organisasi, dengan variabel dependen yaitu kinerja pegawai. Pendekatan kuantitatif digunakan untuk menguji suatu konsep atau teori sehingga dapat dirumuskan hipotesis, untuk menyajikan suatu fakta atau mendeskripsikan statistik, untuk menunjukan hubungan di antara dua atau lebih variabel. Pengujian hipotesis yang digunakan adalah Uji simultan (uji f) digunakan untuk mengetahui besarnya pengaruh variabel bebas, Uji Persial (Uji t) digunakan untuk menguji signifikansi masing-masing variabel bebas $\left(X_{1}\right.$ dan $\left.X_{2}\right)$ secara persial terhadap variabel terikat $(Y)$ atau untuk mengetahui pengaruh yang paling signifikan diantara variabel budaya dan iklim organisasi Politeknik Pertanian Negeri Pangkajenen Kepulauan terhadap kinerja pegawai, dan Analisis determinasi dalam regresi linier berganda digunakan untuk mengetahui persentase pengaruh variabel bebas secara serentak terhadap variabel terikatnya.

\section{HASIL DAN PEMBAHASAN}

\section{Karakteristik Responden}

Berdasarkan hasil penelitian, data jenis kelamin menunjukkan bahwa jumlah responden perempuan sebanyak 62 orang dan responden laki-laki sebanyak 38 orang. Hal ini menunjukan bahwa mayoritas responden adalah perempuan. data menurut masa kerja menunjukkan bahwa rata-rata responden dalam penelitian ini berada pada usia produktif. Responden yang berada dikisaran umur 20 35 tahun sebanyak 32 responden, umur $36-$ 45 tahun sebanyak 41 responden dan umur $>$ 46 tahun sebanyak 27 responden. Dapat dilihat bahwa dari 100 responden sebanyak 55 responden berada pada masa kerja $(>10)-(\leq$ 25) tahun, dan sebanyak 30 responden dengan tingkat umur berada pada masa kerja $(>25)-$ 40 tahun. Pada masa kerja $\leq 10$ tahun hanya sebanyak 15 responden. Tingkat pendidikan responden terbanyak ada pada tingkat $\mathrm{S} 1$ sebanyak 40 responden disusul S2 sebanyak 35 responden dan S3 sebanyak 20 responden dan tingkat pendidikan D3 sebanyak 5 responden.

\section{Budaya Organisasi $\left(\mathrm{X}_{1}\right)$}

Tingkat komitmen pegawai Politani Pangkep terhadap nilai-nilai dan keyakinan dari pimpinan hingga ke semua pegawai dapat mempengaruhi tinggi rendahnya budaya organisasi. Faktor nilai dan keyakinan dasar 
tersebut sangat berperan dalam membentuk etika, sikap, perilaku anggota organisasi dan membentuk cara pandang terhadap masalah. Menurut Uha (2015), mendefinisikan bahwa budaya organisasi adalah nilai-nilai yang menjadi pegangan sumber daya manusia dalam menjalankan kewajiban dan perilaku didalam organisasi. Untuk membagun komitmen tinggi diperlukan dukungan suatu budaya institusi yang positif. Budaya organisasi pegawai Politani Pangkep terlihat pada jumlah responden yang memberi tanggapan pada katagori sangat setuju dengan rata-rata skor 55,6 dengan jumlah skor sebesar 278. Sementara yang memilih kategori setuju rata rata skor 41 , dan yang memberikan tanggapan ragu-ragu rata-rata skor 3,4 dari skala jawaban. Nilai rata - rata sangat setuju dari variabel budaya organisasi yang artinya budaya organisasi dikategorikan sangat baik.

\section{Iklim Organisasi $\left(X_{2}\right)$}

Era revolusi industri 4.0 saat ini akan dihadapi dibidang pelayanan pendidikan yang dapat menimbulkan secercah harapan akan peluang meningkatkan pelayanan, hal tersebut dapat memberikan pengaruh yang penting dalam meningkatkan kompetisi di sektor pendidikan. Dengan meningkatnya tututan pelayanan turut memberikan warna diera globalisasi dan memacu institusi untuk memberikan layanan terbaiknya agar tidak dimarginalkan. Bangun (2012) mendefinisikan kinerja adalah hasil pekerjaan yang dicapai seseorang bedasarkan persyaratan-persyaratan pekerjaan. Mutu pelayanan pendidikan sangat mempengaruhi kualitas pelayanan pendidikan, bahkan menjadi salah satu faktor penentu citra institusi pelayanan pendidikan. Iklim organisasi pegawai Politani Pangkep ini terlihat pada skor responden yang memberi tanggapan pada katagori sangat setuju dengan rata-rata skor 55. Responden yang memberikan tanggapan dalam kategori setuju dengan rata-rata skor 39,2 dan responden yang memberikan tanggapan dalam kategori ragu-ragu dengan rata-rata skor 5,8. Nilai rata-rata sangat setuju dari variabel iklim organisasi yang artinya budaya organisasi dikategorikan baik.

\section{Kinerja Pegawai (Y)}

Penegasan tentang mutu pekerjaan seorang pegawai yang dianggap baik, tepat dan benar yang dirumuskan dan digunakan sebagai pedoman dalam pemberian pelayanan pendidikan serta tolak ukur dalam penampilan kerja seorang pegawai. Setiap upaya untuk meningkatkan kualitas pelayanan institusi harus juga disertai upaya untuk meningkatkan kualitas pelayanan pendidikan. Pada variabel kinerja pegawai diberikan pertanyaan yang mewakili indikator kinerja. Kinerja pegawai Politani Pangkep ini terlihat pada jumlah responden yang memberi tanggapan pada katagori sangat setuju dengan rata-rata skor 56,4 . Responden yang memberikan tanggapan dalam kategori setuju dengan rata-rata skor 37,8 dan responden yang memberikan tanggapan dalam kategori ragu-ragu dengan rata-rata skor 5,8. Nilai rata - rata sangat setuju dari variabel kinerja pegawai yang artinya budaya organisasi dikategorikan baik.

\section{Analisis Regresi, Koefisen Korelasi dan Determinan}

Analisis regresi linier berganda adalah variabel yang diangkat lebih dari dua variabel dengan menggunakan satu variabel dependen dengan beberapa variabel independen. Hubungan antara dua variabel bebas dan variabel terikat ditunjukan dengan persamaan regresi linier berganda. Berdasarkan hasil uji persamaan regresi linier berganda yang ditunjukkan pada Tabel 1 menunjukkan bahwa $Y=5,052+$ $0,206 X_{1}+0,291 X_{2}$, dari persamaan tersebut dapat dilihat bahwa keseluruhan variabel bebas budaya organisasi $\left(\mathrm{X}_{1}\right)$ dan iklim organisasi $\left(\mathrm{X}_{2}\right)$ berpengaruh positif terhadap kinerja pegawai dan diinterpretasikan sebagai berikut:

1. Rata -rata kinerja karyawan sebesar 5,052, jika variabel bebas tidak ada

2. Kinerja pegawai akan meningkat sebesar 0,298 satuan untuk setiap tambahan satu satuan $\mathrm{X}_{1}$ (budaya organisasi). Jadi apabila budaya organisasi mengalami peningkatan 1 satuan, maka kinerja pegawai akan meningkat sebesar 0,206 satuan dengan asumsi variabel yang lainnya dianggap konstan.

3. Kinerja Karyawan akan meningkat sebesar 0,206 satuan untuk setiap tambahan satu satuan $\mathrm{X}_{2}$ (iklim organisasi). Jadi apabila 
iklim organisasi mengalami peningkatan 1 satuan, maka kinerja pegawai akan meningkat sebesar 0,291 satuan dengan asumsi variabel yang lainnya dianggap konstan.

Tabel 1. Rekapitulasi hasil uji regresi linier berganda.

\begin{tabular}{cccccc}
\hline \multirow{2}{*}{$\begin{array}{c}\text { Variabel } \\
\text { Bebas }\end{array}$} & \multicolumn{2}{c}{$\begin{array}{c}\text { Unstandardized } \\
\text { Coefficients }\end{array}$} & $\begin{array}{c}\text { Standardized } \\
\text { Coefficients }\end{array}$ & T & Sig. \\
\cline { 2 - 4 } & $\mathbf{B}$ & Std. Error & Beta & & \\
\hline (Constant) & 5.052 & 3.387 & & 1.492 & 0.098 \\
$\mathbf{X}_{\mathbf{1}}$ & 0.206 & 0.085 & 0.339 & 3.506 & 0.001 \\
$\mathbf{X}_{\mathbf{2}}$ & 0.195 & 0.084 & 0.225 & 2.324 & 0.024 \\
\hline
\end{tabular}

Hasil koefisien korelasi hasil uji terlihat pada Tabel 2 adalah sebesar 0,687 yang menunjukkan besarnya hubungan antara variabel bebas budaya dan iklim organisasi dengan variabel kinerja pegawai. Nilai koefisien korelasi menunjukkan hubungan kategori kuat karena berada pada selang 0,6-0,8 yang bersifat positif yang artinya jika variabel bebas semakin ditingkatkan, maka kinerja pegawai juga akan mengalami peningkatan. Sementara itu, hasil uji koefisien determinan $\left(R^{2}\right)$ sebesar 0,568 menunjukkan bahwa 56,8 persen variabel kinerja pegawai akan dipengaruhi oleh variabel bebas yaitu budaya dan iklim organisasi dan sisanya 43,2 persen variabel kinerja pegawai akan dipengaruhi oleh variabelvariabel lain yang tidak dibahas dalam penelitian ini.

Berdasarkan hasil uji nilai $\mathrm{F}_{\text {hitung }}$ diperoleh nilai $F_{\text {hitung }}$ sebesar 38,099 . Sedangkan $F_{\text {tabel }}(\alpha$ $=0.05 ; \mathrm{db}$ regresi $=2: \mathrm{db}$ residual $=53$ ) adalah sebesar 3,172. Karena $F_{\text {hitung }}>F_{\text {tabel }}$ yaitu $38,099>3,172$ atau nilai sig $F(0,000)<\alpha=$ 0.05 maka model analisis regresi adalah signifikan. Hal ini berarti $\mathrm{HO}$ ditolak dan $\mathrm{H} 1$ diterima sehingga dapat disimpulkan bahwa variabel terikat (kinerja pegawai) dapat dipengaruhi secara signifikan oleh variabel bebas budaya organisasi $\left(X_{1}\right)$, iklim organisasi
$\left(\mathrm{X}_{2}\right)$. Jadi dapat disimpulkan bahwa $\mathrm{HO}$ ditolak dan $\mathrm{H} 1$ diterima, artinya secara simultan terdapat pengaruh yang signifikan antara budaya organisasi dan iklim organisasi terhadap kinerja pegawai. $t_{\text {test }}$ antara $X_{1}$ dengan $Y$ menunjukkan $t_{\text {hitung }}=3,506$. Sedangkan $t_{\text {tabel }}$ $(a=0.05 ; d b$ residual $=53)$ adalah sebesar 2,006 . Karena $t_{\text {hitung }}>t_{\text {tabel }}$ yaitu $3,506>2,006$ atau nilai sig $t(0,001)<\alpha=0.05$ maka pengaruh $\mathrm{X}_{1}$ terhadap kinerja pegawai adalah signifikan. Hal ini berarti $\mathrm{H} 0$ ditolak dan $\mathrm{H} 1$ diterima sehingga dapat disimpulkan bahwa kinerja pegawai dapat dipengaruhi secara signifikan oleh budaya organisasi atau dengan meningkatkan budaya organisasi maka kinerja pegawai akan mengalami peningkatan secara nyata. $t_{\text {test }}$ antara $X_{2}$ dengan $Y$ menunjukkan $t_{\text {hitung }}=2,324$. Sedangkan $t_{\text {tabel }}(\alpha=0.05 ; d b$ residual $=53$ ) adalah sebesar 2,006. Karena $t_{\text {hitung }}>t_{\text {tabel }}$ yaitu 2,324 $>2,006$ atau nilai sig $t$ $(0,024)<\alpha=0.05$ maka pengaruh $X_{2}$ terhadap kinerja pegawai adalah signifikan pada alpha 5 persen. Hal ini berarti $\mathrm{H} 0$ ditolak dan $\mathrm{H} 1$ diterima sehingga dapat disimpulkan bahwa kinerja pegawai dapat dipengaruhi secara signifikan oleh iklim organisasi atau dengan meningkatkan iklim organisasi maka kinerja karyawan akan mengalami peningkatan secara nyata.

Tabel 2. Pengujian hipotesis uji simultan (uji F)

\begin{tabular}{lccccr}
\hline Model & $\begin{array}{c}\text { Sum of } \\
\text { Squares }\end{array}$ & Df & $\begin{array}{c}\text { Mean } \\
\text { Square }\end{array}$ & F & Sig. \\
\hline Regression & 416.963 & 2 & 208.481 & 38.099 & 0.000 \\
\hline Residual & 290.019 & 53 & 5.472 & & \\
\hline Total & 706.982 & 55 & & & \\
\hline
\end{tabular}




\section{Pengaruh Budaya Organisasi $\left(X_{1}\right)$ Terhadap Kinerja Pegawai (Y)}

Budaya organisasi dalam penelitian ini diukur dengan indikator pemberdayaan pegawai Politani Pangkep, orientasi tim, visi, kejelasan arah dan tujuan institusi. Berdasarkan hasil analisis regresi linear berganda, variabel budaya oganisasi $\left(X_{1}\right)$ dan iklim organisasi $\left(X_{2}\right)$ memiliki nilai sig $F(0,000)<\alpha=0.05$ sehingga variabel budaya organisasi dan iklim organisasi memiliki pengaruh yang signifikan terhadap kinerja pegawai. Berdasarkan nilai R Square diketahui bahwa variabel budaya organisasi $\left(X_{1}\right)$ dan iklim organisasi $\left(X_{2}\right)$ memberikan pengaruh atau kontribusi terhadap variabel kinerja pegawai $(\mathrm{Y})$ sebesar 0,568 atau 56,8 persen dan sisanya dipengaruhi oleh variabelvariabel lain yang tidak dibahas dalam penelitian ini. Selain itu, berdasarkan nilai $R$ (koefisien korelasi) sebesar 0.687 yang menunjukkan hubungan antara variabel bebas yaitu budaya organisasi $\left(X_{1}\right)$ dan iklim organisasi $\left(X_{2}\right)$ dengan varibel terikat kinerja pegawai termasuk dalam kategori yang kuat. Dengan demikian dapat disimpulkan bahwa budaya organisasi dan iklim organisasi yang dimiliki Politani Pangkep merupakan faktor yang sangat penting dalam peningkatan kinerja pegawai didalamnya. Pengaruh budaya organisasi terhadap kinerja karyawan berdasarkan hasil uji $t$ variabel budaya organisasi $\left(\mathrm{X}_{1}\right)$ diperoleh signifikansi nilai sig $\mathrm{t}<$ $\alpha=0.05$, sehingga variabel budaya organisasi memiliki pengaruh yang signifikan terhadap kinerja pegawai. Berdasarkan hasil analisis dalam penelitian ini menunjukkan bahwa ratarata jawaban pada variabel budaya organisasi adalah berkategori sangat kuat yaitu dengan nilai rata - rata skor sebesar 55,6. Hal ini membuktikan bahwa pegawai Politani Pangkep setuju dalam bertanggung jawab atas keputusan dan tindakan yang dijalankan, menghormati hak individual dan keragaman, menjunjung tinggi kejujuran dan kewajaran, saling terbuka sesama anggota, mengutamakan kepentingan institusi diatas kepentingan pribadi, kelompok atau golongan, memberikan kualitas layanan terbaik, berdoa sebelum memulai pekerjaan, melakukan senam sebelum memulai pekerjaan, sharing sebelum memulai pekerjaan, dan melindungi kerahasiaan informasi institusi, maka dapat disimpulkan bahwa institusi dimana pegawai bekerja mempunyai budaya organisasi yang sangat kuat. Hasil penelitian yang dilakukan dalam penelitian ini dapat disimpulkan bahwa budaya organisasi memiliki pengaruh yang signifikan terhadap kinerja pegawai.Penelitian ini sesuai dengan penelitian yang dilakukan oleh Novziransyah (2017) dan Radianto dan Sunuharyo (2017) telah melaporkan bahwa terdapat pengaruh budaya organisasi terhadap kinerja karyawan.

\section{Pengaruh Iklim Organisasi $\left(\mathbf{X}_{2}\right)$ Terhadap Kinerja Pegawai (Y)}

Pengaruh iklim organisasi terhadap kinerja pegawai berdasarkan hasil uji $\mathrm{t}$ variabel iklim organisasi $\left(\mathrm{X}_{2}\right)$ diperoleh signifikansi nilai sig $\mathrm{t}<$ $\alpha=0.05$, sehingga variabel iklim organisasi memiliki pengaruh yang signifikan terhadap kinerja pegawai. Berdasarkan hasil analisis dalam penelitian ini menunjukkan bahwa ratarata jawaban pada variabel iklim organisasi adalah berkategori sangat baik yaitu dengan nilai rata - rataskor sebesar 55. Hal ini membuktikan bahwa pegawai setuju dalam pemberian kompensasi berupa cuti, adanya rasa percaya satu sama lain, adanya kebanggaan menjadi bagian dari kelompok, menyelesaikan pekerjaan tanpa merasa dibatasi peraturan, institusi mendukung kreativitaspegawai, memberikan kualitas layanan tebaik, dan melakukan pekerjaan dengan jujur, maka dapat disimpulkan bahwa instansi dimana pegawai bekerja mempunyai iklim organisasi yang kuat.Penelitian ini mendukung penelitian sebelumnya Radianto dan Sunuharyo (2017) menemukan bahwa terdapat pengaruh signifikan iklim organisasi terhadap kinerja karyawan.

\section{Pengaruh Budaya Organisasi $\left(X_{1}\right)$ dan Iklim Organisasi $\left(X_{2}\right)$ secara Simultan Terhadap Kinerja Pegawai (Y)}

Berdasarkan hasil analisis regresi linier berganda yang digunakan, variabel budaya organisasi $\left(X_{1}\right)$ dan iklim organisasi $\left(X_{2}\right)$ memiliki nilai sig $F(0,000)<\alpha(0,05)$, sehingga variabel budaya organisasi dan iklim organisasi memiliki pengaruh yang signifikan terhadap kinerja pegawai, karena dapat dibuktikan dengan Fhitung $=38.099>F_{\text {tabel }} \quad 3,172$ maka model analisis regresi adalah signifikan. dan berdasarkan nilai $\mathrm{R}$ Square diketahui bahwa 
variabel budaya organisasi $\left(\mathrm{X}_{1}\right)$ dan iklim organisasi $\left(X_{2}\right)$ memberikan pengaruh atau kontribusi terhadap kinerja karyawan (Y) sebesar 56,8 persen dan sisanya dipengaruhi oleh variabel lain yang tidak dibahas dalam penelitian ini. Dengan demikian dapat disimpulkan bahwa Iklim organisasi dan budaya organisasi merupakan faktor yang penting di Politani Pangkep dalam meningkatkan kinerja karyawan didalamnya. Politani Pangkep memiliki budaya organisasi dan iklim organisasi yang kuat sehingga berdampak baik pada kinerja pegawai. Pihak institusi harus senantiasa mengontrol perilaku pegawai agar karakteristik institusi tetap terjaga dan kinerja karyawan dapat terus meningkat untuk menunjang proses pencapaian tujuan institusi.

\section{KESIMPULAN}

Budaya organisasi, iklim organisasi dan kinerja yang dimiliki pegawai Politani Pangkep berada dalam kategori kuat, sehingga berdampak baik pada kinerja pegawai. Kinerja pegawai dapat dipengaruhi secara signifikan oleh budaya organisasi dan iklim organisasi atau dengan meningkatkan budaya organisasi dan iklim organisasi maka kinerja pegawai akan mengalami peningkatan secara nyata. Pihak institusi harus senantiasa mengontrol perilaku pegawai agar karakteristik institusi tetap terjaga dan kinerja karyawan dapat terus meningkat untuk menunjang proses pencapaian tujuan institusi.

\section{DAFTAR PUSTAKA}

Bangun, W. 2012. Manajemen Sumber Daya Manusia. Erlangga, Jakarta.

FCGI. 2001. Corporate Governance; Tata Kelola Perusahaan. FCGI, Jakarta.

Novziransyah, N. 2017. Pengaruh budaya organisasi terhadap kinerja karyawan PT. PLN (Persero) kantor wilayah Sumatera Utara Medan. Jurnal JUMANTIK Vol.2(1): 13-25.

Radianto, A dan Sunuharyo, B.S. 2017. Pengaruh iklim organisasi dan budaya organisasi terhadap kinerja karyawan (studi pada karyawan PT. PG Krebet Baru Malang). Jurnal Administrasi Bisnis (JAB) Vol. 53(1): 14-20.

Robbins, S.P. 2008. Perilaku Organisasi. PT. Indeks, Kelompok Gramedia, Jakarta.

Uha, I.N. 2015. Budaya Organisasi Kepemimpinan dan Kinerja: Proses Terbentuk, Tumbuh Kembang, Dinamika, dan Kinerja Organisasi. Edisi ke-1. Kencana, Jakarta.

Wibowo. 2014. Manajemen Kinerja. Edisi ke-4. Rajawali Pers, Jakarta.

Wirawan. 2008. Budaya dan Iklim Organisasi (Teori Aplikasi dan Penelitian). Salemba Empat, Jakarta. 